\title{
Béta-myozin nehézlánc- és miozinkötő C-fehérje gén kettős mutáció azonosítása malignus megjelenésú hipertrófiás cardiomyopathia hátterében
}

\author{
Nagy Viktória1, Pálinkás Attila², Tringer Annamária1, Lidia Hategan1, \\ Csányi Beáta', Pálinkás Eszter', Borbás János', Hegedűs Zoltán ${ }^{3,4}$, \\ Nagy István ${ }^{5,6}$, Sepp Róbert ${ }^{1}$
}

\author{
${ }^{1}$ Szegedi Tudományegyetem, II. sz. Belgyógyászati Klinika és Kardiológiai Központ, Szeged \\ ${ }^{2}$ Erzsébet Kórház, Hódmezővásárhely \\ ${ }^{3}$ Biofizikai Intézet, Szegedi Biológiai Központ, Szeged \\ ${ }^{4}$ Pécsi Tudományegyetem, Biokémiai és Orvosi Kémiai Intézet, Pécs \\ ${ }^{5}$ Biokémiai Intézet, Szegedi Biológiai Központ, Szeged \\ ${ }^{6}$ Seqomics Biotechnológiai Kft., Mórahalom
}

Levelezési cím: Dr. Sepp Róbert, Szegedi Tudományegyetem, II. sz. Belgyógyászati Klinika és Kardiológiai Központ, 6725 Szeged, Semmelweis u 8. E-mail: sepprobert@gmail.com

Háttér: A hipertrófiás cardiomyopathia (HCM) a myocardium primer betegsége, amelyet típusosan a sarcomer fehérjéket kódoló gének mutációi okoznak. Néhány betegben nemcsak egy, hanem több kóroki mutációi is igazolható, ezekben az esetekben irodalmi adatok szerint a betegség klinikai lefolyása súlyosabb.

Betegek és módszerek: Munkánkban egy olyan család genetikai analízisének eredményét mutatjuk be, ahol mind a két szülő HCM-ben szenvedett. Az édesanya betegségét 12 éves korában diagnosztizálták, betegségét típusos aszimmetrikus hipertrófia jellemezte (interventrikuláris septumvastagság: $21 \mathrm{~mm}$ ), bal kamrai kifolyótraktus obstrukció nélkül. Bár rizikóbecslése magas hirtelen szívhalál rizikóra nem utalt, harminckét éves korában úszás közben hirtelen szívhalált halt. Az édesapa betegsége 37 éves korában lett ismert, nonobstruktív HCM formájában, 22 mm-es septumvastagsággal. Béta-blokkoló terápia mellett stabil klinikai állapotban van jelenleg is. Egyik kisfiuk érintettsége 2 éves kora óta volt ismert, amelyet non-obstruktív HCM jellemzett, 22 mm-es septumvastagsággal, gradiens nélkül, diasztolés diszfunkcióval. Progresszív biventrikuláris szívelégtelenség miatt 13 éves korában életét vesztette. A családban genetikai vizsgálat történt, új generációs szekvenálás módszerével, amely során összesen 103, ismerten cardiomyopathiát okozó gén célzott szekvenálására került sor.

Eredmények: A genetikai analízis során két kórokinak tartható sarcomer génmutációt észleltünk a családban. Az egyik a béta-miozin nehézlánc-gént (MYH7 p.Arg719Gln), a másik a miozinkötő C-fehérje gént (MYBPC3 p.Ser593ProfsTer11) érintette. Az édesanya a MYH7 p.Arg719GIn génmutációt, az édesapa a MYBPC3 p.Ser593ProfsTer11 génmutációt, míg a legsúlyosabb formában érintett kisfiú mindkét génmutációt hordozta.

Összefoglalás: A malignus formában megjelenő, progresszív betegséghez és korai szívhalálhoz vezető HCM okaként a két legfontosabb sarcomer gén kettős mutációja valószínüsíthető.

Kulcsszavak: hipertrófiás cardiomyopathia, génmutáció, új generációs szekvenálás 
Beta myosin heavy chain and myosin binding protein $\mathbf{C}$ gene double mutation in hypertrophic cardiomyopathy with a malignant phenotype

Background: Hypertrophic cardiomyopathy $(\mathrm{HCM})$ is a primary disease of the myocardium, caused by mutations in sarcomeric genes. Patients may carry more than one causative mutation, which leads to more severe disease.

Patients and methods: We report the results of genetic analysis of a family where both parents suffered from HCM. The mother was diagnosed having $\mathrm{HCM}$ at the age of 12 , characterized by typical asymmetric hypertrophy (septal thickness: $21 \mathrm{~mm}$ ). Although risk stratification didn't indicate high risk for sudden cardiac death, she died suddenly at the age of 32. The father's illness became known at age of 37 in the form of non-obstructive HCM with septal hypertrophy of 22 $\mathrm{mm}$. $\mathrm{HCM}$ in of one of their sons was known since the age of 2, as non-obstructive HCM with a septal thickness of 22 $\mathrm{mm}$, with diastolic dysfunction. He died of progressive biventricular heart failure when he was 13 . Genetic analysis was performed in the family with targeted resequencing of 103 known causative cardiomyopathy genes.

Results: Genetic analysis revealed two causative sarcomeric gene mutations in the family. One of them affected the beta myosin heavy chain gene (MYH7 p.Arg719GIn) while the other affected the myosin binding protein $\mathrm{C}$ gene (MYBPC3 p.Ser593ProfsTer11). The mother carried the MYH7 p.Arg719GIn mutation the father carried the MYBPC3 p.Ser593ProfsTer11 mutation, while their son, affected by the most severe form of the disease, carried both of the mutations. Conclusion: Double mutation affecting the two most important sarcomeric genes is the most likely explanation for the malignant disease in the son, characterized by progressive disease and early death.

Keywords: hypertrophic cardiomyopathy, gene mutation, next generation sequencing

\section{Bevezetés}

A hipertrófiás cardiomyopathia (HCM) a bal kamra hipertrófiájával jellemezett primer myocardium betegség, ahol a hipertrófia mértékét nem magyarázzák egyéb abnormis nyomásviszonyok (1). Genetikai vizsgálatok igazolták, hogy a HCM az esetek többségében örökletes betegség és a familiáris ioncsatorna-betegségekhez (2-4) hasonlóan típusosan Mendeli, autoszomális domináns öröklődést mutat, változó penetranciával és expresszióval. Molekuláris genetikai módszerekkel specifikus, elsősorban sarcomer fehérjéket kódoló gének eltéréseit találták a betegség hátterében, többek között a béta-miozin nehézlánc [MYH7, (5)]; alfa-tropomiozin [TPM1, (6)]; troponin-T [TNNT2, (6)]; miozinkötő C-fehérje [MYBPC3, (7-9)]; troponin I [TNNI3, (10)]; esszenciális $[M Y L 3,(11)])$ és regulatórikus miozin könynyűlánc $[M Y L 2,(11)]$; aktin [ACTC1, (12)] és titin [TTN, (13)] gén érintettségével. Mindezek alapján a HCM-et típusos esetben a sarcomer betegségének tekintjük, amelyeket el kell különítenünk más génelváltozások által okozott HCM fenokópiáktól $(14,15)$.

Legújabb, új generációs szekvenáláson alapuló adatok szerint a HCM-ben leggyakrabban érintett gén a miozinkötő C-fehérje gén (MYBPC3), amelyet nem szelektált HCM-populáció 20\%-ban, a mutáció pozitív esetek 50\%-ában lehet kimutatni. A másik legfontosabb HCMgén a béta-miozin nehézlánc-gén ( $M Y H 7)$, amelyet nem szelektált HCM-populáció 10\%-ában, a mutáció pozitív esetek 25\%-ában lehet kimutatni (16). A MYH7gént érintő mutációk többségükben „missense” mutációk, amelyek eredményeképpen egyetlen aminosav cseréje következik be. A MYBPC3-mutációk megköze- lítőleg 2/3 része ún. „splice-site” mutáció, vagy nukleotid inzerció/deléció, amelyek a leolvasási keret eltolódását okozzák, amelyeket korai stop-kodon aktiváció zár le. Utóbbiak a normálisnál rövidebb, csonkolt fehérjét eredményeznek (17).

Munkacsoportunk 2001-ben publikálta az első HCM-et okozó génmutációt a béta-miozin nehézlánc-génben [MYH7 p.Arg719GIn, (18)] egy olyan családban, ahol a mutációt hordozó index beteg édesanya harminckét éves korában úszás közben hirtelen szívhalált halt. Még malignusabb klinikai megjelenést észleltünk az egyik érintett kisfiában, akiben a betegség korai életkorban jelentkezett, és progresszív szívelégtelenség miatt 13 éves életkorban halálhoz vezetett. A család utánkövetése során mellékleletként igazolódott, hogy az index beteg férje, az édesapa is típusos HCM-ben szenved. Az édesapa genetikai vizsgálatára az új generációs szekvenálási metodikák bevezetésével nyílt lehetőségünk, amely egy második, a miozinkötő $\mathrm{C}$-fehérje gént (MYBPC3 p.Ser593ProfsTer11) érintő mutációt igazolt. A legsúlyosabb formában érintett kisfiú mind az anyai MYH7 p.Arg719GIn, mind az apai MYBPC3 p.Ser593ProfsTer11 génmutációt hordozta. Utóbbi valószínúsíthető a súlyos morfológiai képpel és lefolyással járó HCM okaként.

\section{Betegek és módszerek}

\section{Betegek}

$A z$ index beteg és érintett kisfia kórtörténetét korábban már részleteiben publikáltuk (18). Röviden összefoglalva, az index beteg hipertrófiás cardiomyopathiá- 
ját 12 éves korban, szívzörej alapján indult kivizsgálása során állapították meg. Béta-blokkoló kezelés mellett stabil klinikai állapotban volt, ideiglenesen jelentkező effort dyspnoes, szédüléses és palpitációval járó panaszok miatt időnkénti hospitalizációkra került sor, de eszméletvesztés, tromboembóliás szövődmény vagy kifejezett dekompenzációra utaló tünetek nem jelentkeztek követése során. 24 órás ambulanter Holter-monitorozása 1\%-ot elérő kamrai extrasystoliát, néhány kapcsolt VES-et mutatott, de major kamrai ritmuszavart nem lehetett detektálni. Utolsó ambulanter kontrolljakor (31 éves korában) echokardiográfiás vizsgálata típusos ASH-t (parasternális hossztengelyi metszeten mérve interventrikuláris septumvastagság: $21 \mathrm{~mm}$, bal kamra hátsó fal vastagság: $9 \mathrm{~mm}$ ), kissé tágabb bal pitvart (bal pitvari átmérő: $43 \mathrm{~mm}$ ), enyhén dilatált bal kamrai paramétereket (bal kamrai végdiasztolés átmérő: $55 \mathrm{~mm}$, bal kamrai végszisztolés átmérő: $40 \mathrm{~mm}$ ), normális bal kamrai szisztolés funkciót (bal kamrai ejekciós frakció: $52 \%$ ), abnormis bal kamrai relaxációt (E/A: 48/68) és jelzett mitrális inszufficienciát mutatott. Bal kamrai kifolyótraktus-obstrukció nem volt detektálható. Egy évvel később uszodában való úszás közben hirtelen szívhalált halt.

Az index beteg egy négygenerációs családból származott, amelynek családfája az 1. ábrán látható. A család minden tagja, összesen 14 személy, részt vett a családszürő vizsgálaton. $A z$ index beteg szüleinek (I:1; I:2) szívbetegségre utaló panaszai nem voltak, EKGjuk normális volt, echokardiográfiás vizsgálatuk enyhe, koncentrikus balkamra-hipertrófiát igazolt, feltételezhetően a több éve fennálló mérsékelt hipertónia következményeként. Az index beteg négy testvérének és azok gyermekeinek panaszaik, illetve tüneteik nem voltak, EKG-juk és echokardiogramjuk negatív volt. Az index beteg két fiúgyermeke közül az egyiknél (III:10) 2 éves korában az SZTE Gyermekklinikáján szintén HCM-et állapítottak meg, echokardiográfiás vizsgálattal a septum jelentős megvastagodásával. A panaszmentes gyermeknél 4 éves korában klinikai státuszrevízióra került sor, amely során echokardiogramján hipertrófiás jobb és főleg bal kamrát, igen kifejezett septumhipertrófiát (septumvastagság: $21 \mathrm{~mm}$, hátsó fal: $7,1 \mathrm{~mm}$ ), bal kamrai diasztolés funkciózavart, SAM-jelenséget láttak, béta-blokkoló terápiát indítottak. Terhelhetősége mindvégig alacsony volt, terhelésre nehézlégzés, illetve minimális ajakcianózis jelentkezett. Követése során többször került sor hospitalizációra részben recidív obstruktív bronchitis és bronchopneumónia valamint kardiális státusza miatt. Nyolcéves korában történt ambulanter vizsgálatakor echokardiográfiás vizsgálata a hátsó és posterior falak kivételével valamennyi bal kamrai szegmens és a jobb kamra kifolyótraktusának hipertrófiáját mutatta, legkifejezettebben a septum közepén (interventrikuláris septumvastagság: $22 \mathrm{~mm}$, bal kamra hátsó fal vastagság: $6 \mathrm{~mm}$ ), ezen kívül tág bal pitvart (bal pitvari átmérő: $48 \mathrm{~mm}$ ), tág bal kamrai pa- ramétereket (bal kamrai végdiasztolés átmérő: $56 \mathrm{~mm}$, bal kamrai végszisztolés átmérő: $31 \mathrm{~mm}$ ), jó globális bal kamrai szisztolés funkciót (bal kamrai ejekciós frakció: $68 \%$ ), feltehetőleg pszeudonormális bal kamrai diasztolés funkciót (E/A: 50/33) és egyes fokú mitrális inszufficienciát mutatott. 24 órás Holter-monitoros vizsgálata kórosat nem igazolt. Futószőnyeges terheléses vizsgálatánál alacsony terhelhetőséget (2 MET) és hipotenzív vérnyomásválaszt észleltünk. Betegségét gyors progresszió jellemezte, halála 13 éves korban következett be akut biventrikuláris szívelégtelenség miatt. Az index beteg másik fiúgyermeke klinikailag egészségesnek bizonyult.

Az utánkövetés során mellékleletként igazolódott, hogy az index beteg férje is típusos HCM-ben szenved (2. ábra). (Fentinek, hogy két HCM-es beteg kössön házasságot, kb. 1:250 000-1 000000 az esélye.) Diagnózisát 37 éves korában állítottuk fel. Betegségét non-obstruktív HCM jellemezte, 22 mm-es septumvastagsággal. Béta-blokkoló terápia mellett mind a mai napig stabil klinikai állapotot mutat.

\section{Genetikai analízis}

A család genetikai analízise 2001-ben, single strand conformation polymorphism' (SSCP) vizsgálattal történt, az abnormis migrációt mutató mintában ezt követő direkt kapilláris szekvenálással (18). A kiterjesztett genetikai vizsgálat során az érintett fiú és az édesapa mintájában célzott újraszekvenálással 103, ismert cardiomyopathiát okozó gént vizsgáltunk. Utóbbi az Agilent "SureSelect” technológiát használja egyedi tervezésü, célrégió specifikus 120 bp. hosszú RNS „bait”-ekkel (Agilent Technologies, Santa Clara, CA, United States). A sokszorosított DNS szekvenálását SOLiD 5500x System-el (Life Technologies, Grand Island, NY, United States) végeztük. A SOLiD read-ek mapping-jét a Genomic Workbench ver 7.0.3-al (CLC Bio, Qiagen) végeztük, a Human Genome Assembly hg19-et, mint referenciaszekvenciát használva. A variáns lehívást és variáns annotáció ugyanezzel a szoftverrel készült. A missense mutációk által okozott aminosav-cserék funkcionális hatását a SIFT és PROVEAN predikciós programokkal elemeztük

Az azonosított MYH7- és MYBPC3-variánsok validálásra kerültek direkt kapilláris szekvenálás által (BigDye Terminator v3.1 Cycle Sequencing Kit, Applied Biosystems), amely során a gének kódoló szakaszainak szekvenálása történt meg ABI Prism 310 Genetic Analyzer-en (Applied Biosystems). Az elektroferogramokat a gyártó Sequencing Analyzer v5.4 szoftverével analizáltuk.

\section{Eredmények}

A család 2001-es genetikai vizsgálatakor a béta-miozin nehézlánc-gén (MYH7) 19-es exonjában egy 


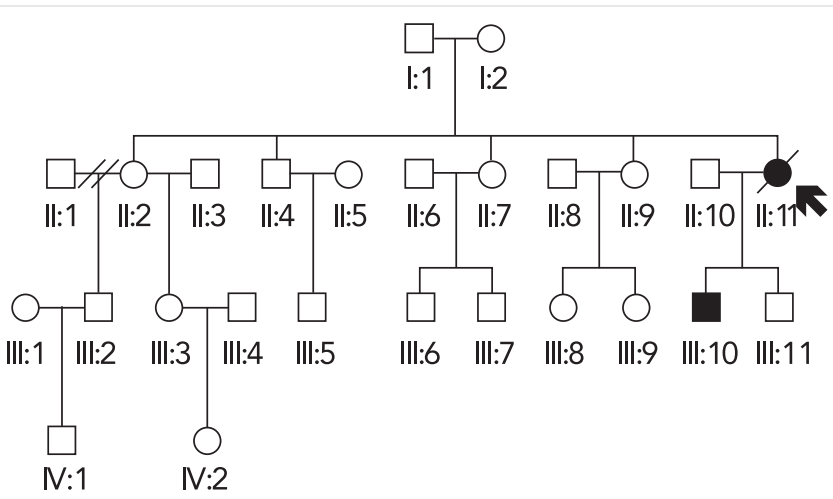

1. ÁBRA. A vizsgált család 2001-ben közölt (18) négygenerációs családfája. A férfiakat négyzet, a nőket kör jelöli, a klinikailag egészséges családtagokat üres, a betegeket kitöltött szimbólum reprezentálja. Az index betegre (II:11) nyíl mutat

p.Arg719GIn (rs121913641) mutációt azonosítottunk (18). A család genetikai analízisekor az index beteg mellett csak a klinikailag érintett fiú (III: 10) mintájában észleltük a mutációt, hasonlóan heterozigóta formában. Mivel a mutációt az index beteg szüleiben nem lehetett igazolni, ez a mutáció, „de novo” eredetére utalt. $A z$ index beteg másik kisfia és a férje nem hordozta a mutációt (1. ábra).

Az új generációs szekvenálás az érintett édesapa mintájában a miozinkötő C-fehérje génben (MYBPC3) azonosított egy 2-bp mikrodeléciót a gén 18-as exonjában, amely egy csonkoló jellegű mutációhoz, p.Ser593ProfsTer11 (rs730880713) mutációhoz vezetett (3. ábra). A variánsokat kapilláris szekvenálással is validáltuk.

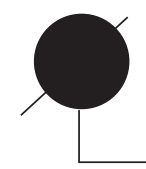

II:10

MYH7 p.Arg719GIn: + MYBPC3 p.Ser593ProfsTer11:-

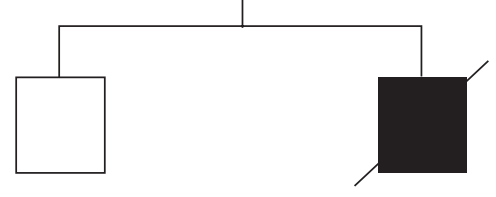

MYH7 p.Arg719Gln:MYBPC3 p.Ser593ProfsTer11:-

MYH7 p.Arg719Gln: + MYBPC3 p.Ser593ProfsTer11: +

2. ÁBRA. A vizsgált család érintett részének revideált családfa-részlete. A férfiakat négyzet, a nőket kör jelöli, a klinikailag egészséges családtagokat üres, a betegeket kitöltött szimbólum reprezentálja. A családtagok azonosítója az 1. ÁBRÁN feltüntetett azonosítókkal megegyezik. A szimbólumok alatti genotípusban a + jel hordozó, a - jel nem hordozó állapotot jelöl
Az érintett fiú mintájában az új generációs szekvenálás a korábbi genetikai adatokat megerősítve pontosan azonosította az anyai ágon örökölt MYH7 p.Arg719GIn-mutációt, és igazolta, hogy a fiú az apai ágon örökölt MYBPC3 p.Ser593ProfsTer11-mutációra is hordozó, így ő kettős mutációhordozónak számít. A másik kisfiú az apai mutációt sem hordozta (2. ábra).

\section{Megbeszélés}

Munkánkban két patogén mutáció, MYH7 p.Arg719GIn és MYBPC3 p.Ser593ProfsTer11-mutáció hordozását mutattuk ki egy HCM-ben szenvedő családban, amely közül az egyik az anyai, a másik az apai ágon öröklődött. A mindkét mutációt hordozó családtagban malignus formában megjelenő, progresszív betegséghez és korai szívhalálhoz vezető betegséget észleltünk.

új generációs szekvenáláson alapuló adatok szerint HCM-ben a multiplex mutációk előfordulási aránya a mutáció pozitív HCM-populációban 3-19\%-ig terjed, átlagban $8 \%$ (19). Kisszámú betegcsoportok vizsgálata és esettanulmányok alapján a multiplex mutációt hordozókban súlyosabb klinikai képet, pl. a betegség korábbi életkorban való kialakulását, súlyosabb balkamra-hipertrófiát, a szívelégtelenség nagyobb prevalenciáját és a hirtelen szívhalál gyakoribb előfordulását írták le (20-22). Mindazonáltal az American College of Medical Genetics and Genomics és az Association for Molecular Pathology (ACMG/AMP) által nemrégen kidolgozott részletes variáns klasszifikáció (23) alapján fenti multiplex variánsok nagy része nem felel meg a patogén/valószínüleg patogén besorolásnak és nagy részük „bizonytalan hatású variáns”-nak (variant of unknown significance, VUS) tartható. Fenti kritériumok alapján a „valóban” két patogén mutációt hordozó betegek aránya a mutáció pozitív HCM-es beteg csoporton belül mindössze 0,4\% (19).

Mindazonáltal két „igazi” patogén mutációt hordozó HCM-es betegekben kifejezett malignus klinikai kép látható. Ez különösen azokban a ritka esetekben észlelhető, amikor egy beteg homozigóta az adott mutációra, tehát mindkét génkópiája mutáns. Egy olyan ámis család 20 családtagjában, akikben a MYBPC3-gén homozigóta „splice-site” mutációja volt kimutatható, a betegség már a neonatális korban kifejlődött, és halálhoz vagy szívtranszplantációhoz vezetett az első életév alatt (24). Olyan további esetek mindegyikében, kikben két „radikális” (nonszensz, frame-shift vagy „splice-site") MYBPC3-mutáció volt kimutatható, a betegség gyermek- vagy kamaszkorban jelentkezett és súlyos klinikai képpel társult (hirtelen szívhalál és szívtranszplantáció végstádiumú szívelégtelenségbe való progresszió miatt).

Fentieket állatkísérletes modellek is megerősítik, amelyek szerint homozigóta „knock-out” egerekben súlyosabb klinikai kép alakul ki, mint heterozigóta formában. 

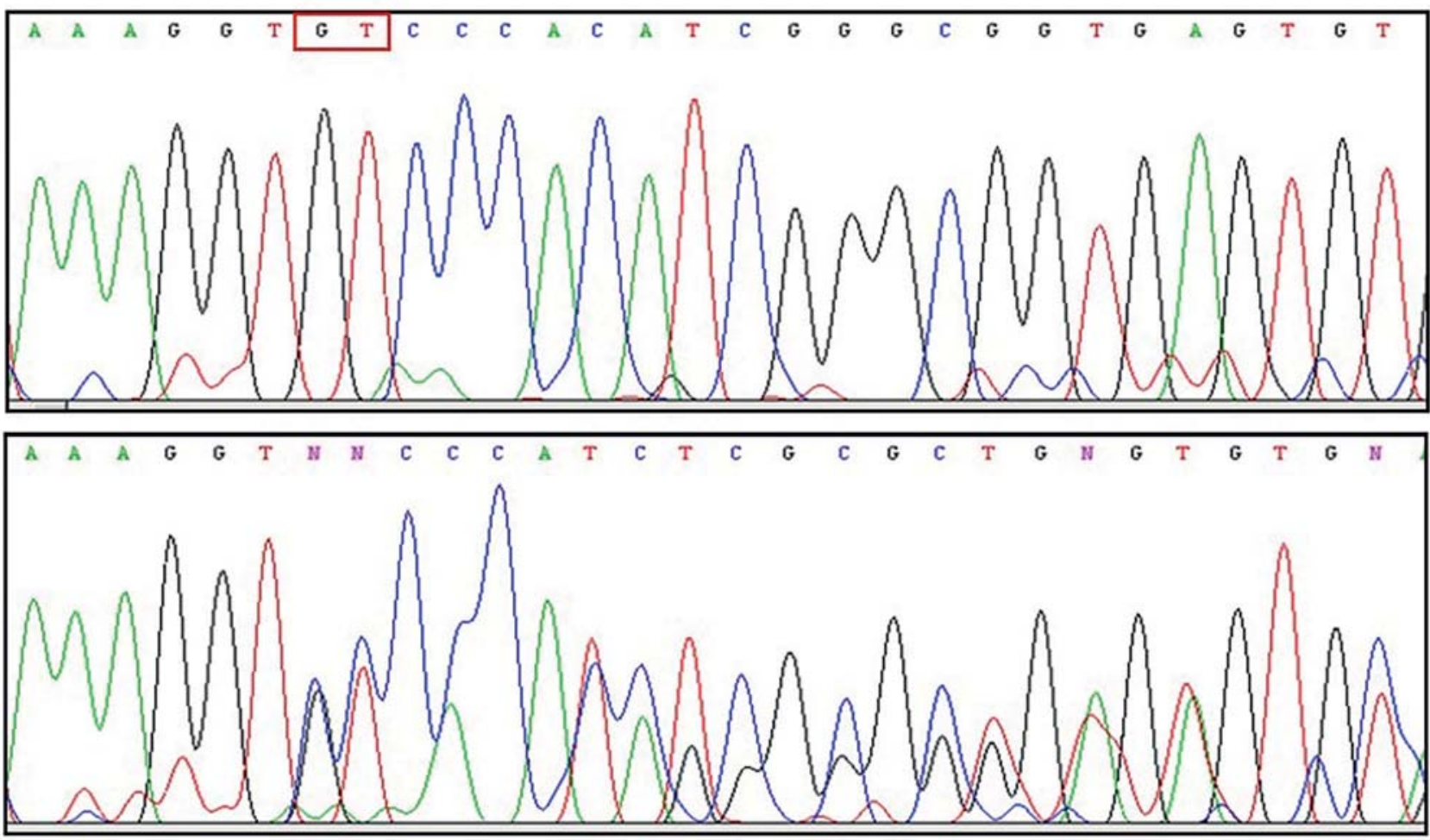

3. ÁBRA. Az édesapában azonosított GT 2-bp mikrodeléció a MYBPC3-gén 18-as exonjában (c.1776_1777delGT), amely p.Ser593ProfsTer11 mutációhoz vezet. Felső panel: normál szekvencia. Alsó panel: mutáns szekvencia

Utóbbit jól példázza a béta-miozin lánc Arg403GIn mutációjának egérmodellje, amelyben homozigóta formában már az első héten súlyos dilatatív cardiomyopathia alakul ki, míg heterozigóta egerekben később, 30-40 hetes korban alakul ki típusos $\operatorname{HCM}(25,26)$. A MYBPC3-gén „knock-out” egérmodelljében hasonló módon homozigóta formában DCM alakul ki már neonatális korban, míg heterozigóta formában, későbbi életkorban HCM fejlődik ki (27). Ezen megfigyelések az ún. „gén-dózis” effektusra utalnak.

Az általunk észlelt kettős mutáció mindegyike patogén mutációnak tartható. A 719-es kodon által kódolt arginin a béta-miozin nehézlánc-protein azon doménjének része, amely a miozin könnyű láncokkal áll interakcióban (28). A béta-miozin nehéz lánc 719-es pozíciójában lévő arginin aminosav az összes felnőtt emlős miozin nehézlánc-szekvenciában megtartott, amely az adott aminosav esszenciális szerepét (strukturális vagy funkcionális) valószínűsíti. A 719-es kodonnál egy másik mutációt is leírtak már [Arg719Trp (29-30)] több, egymással nem rokon családban, amely az adott kodon az átlagosnál magasabb mutációs rátájára utalhat. A MYH7 p.Arg719GIn-mutációt >30 betegben észlelték világszerte és egyértelmű szegregációs adatok is rendelkezésre állnak vele kapcsolatban, ezért az ACMG/ AMP-kritériumok alapján egyértelmű patogén mutációnak tartható. Hasonló a helyzet a MYBPC3-gén p.Ser593ProfsTer11 mutációjával, amely egy „típusos” csonkoló hatású „splice-site” MYBPC3-mutáció, amely a ClinVar adatbázisban egyértelmű patogén besorolással szerepel.

A bemutatott eset a HCM-ben használt hirtelen szívhalál, és általában a betegség prognózisával kapcsolatos rizikóbecslés limitációját is jól jelzi. Bár a genetikai vizsgálat eredményének figyelembevétele nem része fenti algoritmusoknak (1), egyedi esetekben a genetikai analízis eredménye, mint esetünkben is, jelentősen árnyalhatja a klinikai megítélést. A genetikai vizsgálat elvégzése HCM-es betegekben - elsősorban további érintett családtagok igazolása céljából - az ESC-ajánlás szerint IB-szintű (1), de adott esetben a prognózis megítélésében is segítséget nyújthat. Utóbbi miatt is, mint ahogy azt az ESC-ajánlás is javasolja, a HCM-es betegek tercier szintű centrumban történő, multidiszciplináris szemléletű követése javasolt, különösen bizonytalan diagnózis, súlyos panaszok, illetve a betegséghez társuló komplikációk esetén (1).

\section{Ko̊vetkeztetések}

Összefoglalva, munkánkban a malignus formában megjelenő, progresszív betegséghez és korai szívhalálhoz vezető HCM esetében a béta-miozin nehézlánc-gén (MYH7 p.Arg719GIn) és miozinkötő C-fehérje gén (MYBPC3 p.Ser593ProfsTer11) kettős mutációját azonosítottuk. Utóbbi valószínúsíthető a súlyos morfológiai képpel és lefolyással járó HCM okaként. 


\section{Köszönetnyilvánítás \\ A munka a „Ritka betegségek patogenezisének kuta- tása, új diagnosztikai és terápiás eljárásokat megala- pozó fejlesztések" (GINOP-2.3.2-15-2016-00039), az "Életet veSzélyezTető Akut megbetegedések súlYos- sági és hALálozási mutatólnak jaVitása transzlációs orvostudományi mEgközelítésben - STAY ALIVE" (GI- NOP-2.3.2-15-2016-00048) és a Szegedi Tudomány- egyetem ÁOK Kari Kutatási Alap „Hetényi Géza” pályá- zatának támogatásával készült.}

\section{Irodalom}

1. Elliott PM, Anastasakis A, Borger MA, et al. 2014 ESC Guidelines on diagnosis and management of hypertrophic cardiomyopathy the Task Force for the Diagnosis and Management of Hypertrophic Cardiomyopathy of the European Society of Cardiology (ESC). Eur Heart J 2014; 35: 2733-2779. doi: 10.1093/eurheartj/ehu284 2. Sepp R, Hategan L, Bácsi A, et al. Timothy Syndrome 1 Genotype without Syndactyly and Major Extracardiac Manifestations. Am J Med Genet A 2017; 173(3): 784-789. doi: 10.1002/ajmg.a.38084 3. Hategan L, Csányi B, Ördög B, et al. A novel 'splice site' HCN4 gene mutation, c.1737+1 G>T, causes familial bradycardia, reduced heart rate response, impaired chronotropic competence and increased short-term heart rate variability. Int J Cardiol 2017; 241: 364372. doi: 10.1016/j.ijcard.2017.04.058

4. Ördög B, Hategan L, Kovács M, et al. Identification and functional characterisation of a novel KCNJ2 mutation, Val302del, causing Andersen-Tawil syndrome. Can J Physiol Pharmacol 2015; 93(7): 569-75. doi: 10.1139/cjpp-2014-0527

5. Geisterfer-Lowrance AAT, Kass S, Tanigawa G, et al. A molecular basis for familial hypertrophic cardiomyopathy: a beta cardiac myosin heavy chain gene missense mutation. Cell 1990; 62: 999-1006. 6. Thierfelder L, Watkins $\mathrm{H}$, MacRae $\mathrm{C}$, et al. Alpha-tropomyosin and cardiac troponin T mutations cause familial hypertrophic cardiomyopathy: a disease of the sarcomere. Cell 1994; 77: 701-712.

7. Bonne G, Carrier L, Bercovici J, et al. Cardiac myosin binding protein-C gene splice acceptor site mutation is associated with familial hypertrophic cardiomyopathy. Nat Genet 1995; 11: 438-440.

8. Watkins $\mathrm{H}$, Conner D, Thierfelder L, et al. Mutations in the cardiac myosin binding protein- $\mathrm{C}$ gene on chromosome 11 cause familial hypertrophic cardiomyopathy. Nat Genet 1995; 11: 434-437.

9. Toth T, Nagy V, Faludi R, et al. The Gln1233ter mutation of the myosin binding protein $\mathrm{C}$ gene: Causative mutation or innocent polymorphism in patients with hypertrophic cardiomyopathy? Int J Cardiol 2011; 153(2): 216-9. doi: 10.1016/j.ijcard.2011.09.062.

10. Kimura A, Harada H, Park J-E, et al. Mutations in the troponin I gene associated with hypertrophic cardiomyopathy. Nature Gen 1997; 16: 379-382

11. Poetter K, Jiang H, Hassanzadeh S, et al. Mutations in either the essential or regulatory light chains of myosin are associated with a rare myopathy in human heart and skeletal muscle. Nat Genet 1996; 13: 63-69.

12. Mogensen J, Klausen I, Pedersen A, et al. Alpha-cadiac actin is a novel disease gene in familial hypertrophic cardiomyopathy. J Clin Invest 1999; 103: R39-R43.

13. Satoh M, Takahashi M, Sakamoto T, Hiroe M, Marumo F, Kimura A. Structural analysis of the titin gene in hypertrophic cardiomyopathy: identification of a novel disease gene. Biochem Biophys Res Commun 1999; 262: 411-417.

14. Csanyi B, Popoiu A, Hategan L, et al. Identification of two novel LAMP2 gene mutations in Danon disease. Can J Cardiol 2016; 32(11): 1355.e23-1355.e30. doi: 10.1016/j.cjca.2016.02.071
15. Csányi B, Hategan L, Nagy V, et al. Identification of a Novel GLA Gene Mutation, p.lle239Met, in Fabry Disease with a Predominant Cardiac Phenotype. Int Heart J 2017; 58(3): 454-458. doi: 10.1536/ ihj.16-361

16. Lopes LR, Syrris P, Guttmann OP, et al. Novel genotype-phenotype associations demonstrated by high-throughput sequencing in patients with hypertrophic cardiomyopathy. Heart 2015; 101: 294301. doi:10.1136/heartjnl-2014-306387

17. Carrier L, Mearini G, Stathopoulou K, Cuello F. Cardiac myosin-binding protein C (MYBPC3) in cardiac pathophysiology. Gene 2015; 573: 188-197.

18. Sepp R, Pálinkás A, Kertész E, et al. Hipertrófiás cardiomyopathiát okozó génmutáció azonosítása a béta miozin nehéz lánc génben. Az első molekuláris genetikai analízissel igazolt magyar család leírása. Cardiologia Hungarica 2001; 1: 65-70.

19. Fourey D, Care M, Siminovitch KA, et al. Prevalence and clinical implication of double mutations in hypertrophic cardiomyopathy Revisiting the gene-dose effect. Circ Cardiovasc Genet 2017; 10 e001685. DOI: 10.1161/CIRCGENETICS.116.001685.)

20. Biagini E, Olivotto I, lascone M, Parodi MI, Girolami F, Frisso $\mathrm{G}$, et al. Significance of sarcomere gene mutations analysis in the end-stage phase of hypertrophic cardiomyopathy. Am J Cardiol 2014; 114: 769-776. doi:10.1016/j.amjcard.2014.05.065

21. Maron BJ, Maron MS, Semsarian C. Double or compound sarcomere mutations in hypertrophic cardiomyopathy: a potential link to sudden death in the absence of conventional risk factors. Heart Rhythm 2012; 9: 57-63. doi: 10.1016/j.hrthm.2011.08.009

22. Orosz A, Baczko I, Nagy V, et al. Short-term beat-to-beat variability of the QT interval is increased and correlates with parameters of left ventricular hypertrophy in patients with hypertrophic cardiomyopathy. Can J Physiol Pharmacol 2015; 93(9): 765-72. doi: 10.1139/cjpp-2014-0526.

23. Richards S, Aziz N, Bale S, et al. Standards and guidelines for the interpretation of sequence variants: a joint consensus recommendation of the American College of Medical Genetics and Genomics and the Association for Molecular Pathology. Genet Med 2015; 17: $405-424$

24. Xin B, Puffenberger E, Tumbush J, Bockoven JR, Wang H. Homozygosity for a novel splice site mutation in the cardiac myosin-binding protein $\mathrm{C}$ gene causes severe neonatal hypertrophic cardiomyopathy. Am J Med Genet A. 2007; 143A: 2662-2667. doi: 10.1002/ajmg.a.31981

25. Fatkin D, Christe ME, Aristizabal O, McConnell BK, Srinivasan $\mathrm{S}$, Schoen FJ, et al. Neonatal cardiomyopathy in mice homozygous for the Arg403GIn mutation in the alpha cardiac myosin heavy chain gene. J Clin Invest 1999; 103: 147-153. doi: 10.1172/JCI4631

26. McConnell BK, Fatkin D, Semsarian C, Jones KA, Georgakopoulos D, Maguire CT, et al. Comparison of two murine models of familial hypertrophic cardiomyopathy. Circ Res 2001; 88: 383-389. 27. McConnell BK, Jones KA, Fatkin D, Arroyo LH, Lee RT, Aristizabal $\mathrm{O}$, et al. Dilated cardiomyopathy in homozygous myosin-binding protein-C mutant mice. J Clin Invest 1999; 104: 1235-1244. doi: 10.1172/JCl7377

28. Rayment I, Holden H, Sellers J, et al. Structural interpretation of the mutations in the beta-cardiac myosin that have been implicated in familial hypertrophic cardiomyopathy. Proc Natl Acad Sci USA 1995; 92: 3864-8.

29. Anan R, Greve G, Thierfelder L, et al. Prognostic implications of novel beta cardiac myosin heavy chain gene mutations that cause familial hypertrophic cardiomyopathy [see comments]. J Clin Invest 1994; 93: 280-5

30. Jeschke B, Uhl K, Schroder D, et al. A high risk phenotype of hypertrophic cardiomyopathy associated with a compound genotype of two mutated beta-myosin heavy chain genes. Hum Genet 1998; 102: 299-304 